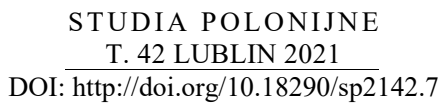

KAROL RZEPECKI

\title{
DZIAŁALNOŚĆ JÓZEFA WIENIAWSKIEGO W LONDYNIE - ANALIZA ŹRÓDEŁ
}

Z dotychczasowych badań dotyczących Józefa Wieniawskiego wynika, że na przestrzeni całej swojej działalności koncertowej, w różnych okresach życia kilkakrotnie odwiedził Londyn. Lokalna prasa regularnie informowała o kolejnych jego poczynaniach w mieście. Były one na tyle istotne, że wzmianki pojawiały się również w źródłach polskich, niemieckich i francuskich. Obok omówienia tego zagadnienia $\mathrm{w}$ niniejszym artykule, należy zwrócić uwagę na dwa inne problemy. Szerokim echem w londyńskiej prasie odbiło się powstanie fortepianu dwuklawiaturowego - instrumentu, jakiego Wieniawski był pomysłodawcą. Warto w tym miejscu przywołać również zagadnienie edycji wybranych utworów przez oficyny w stolicy Wielkiej Brytanii. Opracowanie tych zagadnień pozwoli na pełniejsze poznanie życiorysu pianisty.

Warto zauważyć, że Józef Wieniawski nie był pierwszym polskim kompozytorem, który odwiedził ten kraj. Sam Fryderyk Chopin uczynił to dwukrotnie: w 1837 i 1848 r., kiedy spędził tam aż pięć miesięcy ${ }^{1}$. W lipcu, zasiadając na widowni uczestniczył $w$ koncercie swojego ucznia Ignacego Krzyżanowskiego. Pod koniec lat trzydziestych Londyn gościł przedstawiciela rodziny rywalizującej z duetem braci Wieniawskich - Apolinarego Kątskiego. Z badań Ewy Chamczyk wynika, że skrzypek przybył do miasta 24 lipca 1838 r. $^{2}$, gdzie zaprezentował się kilkakrotnie przed lokalną arystokracją. Główny „cel wyprawy do Londynu został osiągnięty 8 sierpnia 1838 roku, kiedy to Apolinary stanął na dworze królewskim, by dać się usłyszeć królowej

Dr KAROL RzEPECKI - Instytut Nauk o Sztuce na Wydziale Nauk Humanistycznych Katolickiego Uniwersytetu Lubelskiego Jana Pawła II; e-mail: rzepeckkarol3@gmail.com. ORCID: https:// orcid.org/0000-0002-5646-6622.

${ }^{1}$ A. ZAMOYsKi, Chopin, Warszawa 2010, s. 89.

${ }^{2}$ Zob. E. CHAMCZYK, Londyński epizod Apolinarego Kątskiego (1838), „Kwartalnik Młodych Muzykologów UJ" 2019, nr 40 (1), s. 8. 
angielskiej Wiktorii”", odnosząc niebywały sukces, mający wpływ na dalszą karierę. Znaczące zasługi w kształtowaniu kultury muzycznej tego miasta należy przypisać bratankowi króla Stanisława Augusta Poniatowskiego - Józefowi Ksaweremu Poniatowskiemu. Ten polski kompozytor urodzony w Rzymie, autor dwunastu dzieł scenicznych i kilkudziesięciu pieśni wybrał Londyn na osiedlenie się w dojrzałym wieku i premierę opery Gelmina w 1872 r. Józef Wieniawski był jednak polskim pianistą, który odwiedzał to miasto najczęściej.

Biorąc pod uwagę związki Wieniawskich z Londynem, w pierwszej kolejności nie można pominąć koligacji rodzinnych, za sprawą Henryka, co w dużej mierze ułatwiło wniknięcie $\mathrm{w}$ tamtejsze środowisko artystyczne. Otóż w kwietniu 1859 r., podczas wspólnych koncertów z Antonim Rubinsteinem skrzypek poznał Isabelle Bessi Hampton pochodzącą z brytyjsko-irlandzkiej rodziny arystokratycznej, siostrzenicę Alexandra Osbornea ${ }^{4}$. Nieco ponad rok później w St. James Hall doszło do prawykonania Legendy (18 listopada 1860) - jednego z najpopularniejszych utworów kompozytora. Po przedwczesnej śmierci męża Isabelle Wieniawska powróciła z Brukseli do stolicy Wielkiej Brytanii, gdzie zamieszkała u rodziców. Warto w tym miejscu zauważyć, że z Londynem związały się córki Józefa i Melanie Wieniawskich - Elżbieta i Marcelina. Pierwsza prowadziła w mieście działalność artystyczną i kompozytorską ${ }^{5}$, natomiast pod koniec lat siedemdziesiątych XX wieku swoje pamiątki po ojcu w postaci nut i innych rękopisów przekazała do Warszawskiego Towarzystwa Muzycznego. Losy Marceliny są mniej znane. Z miastem związali się również kolejni potomkowie Henryka, a mianowicie córki: Izabela Helena, Henryka Klaudyna i Irena Regina ${ }^{6}$. Niemniej nie zachowały się informacje świadczące o relacjach pomiędzy Józefem Wieniawskim a pozostałymi członkami rodziny zamieszkującymi Wielką Brytanię?

${ }^{3}$ Tamże, s. 10

${ }^{4}$ M. TERLECKA, Irène Régine Wieniawska - próba rekonstrukcji życia i twórczości, „Kwartalnik Młodych Muzykologów UJ" 2019, nr 42 (3), s. 37.

${ }^{5}$ Zagadnienie dotyczące życia i twórczości Elżbiety Wieniawskiej w przyszłości wymaga bardziej szczegółowego omówienia. O jej działalności koncertowej na bieżąco informowała londyńska prasa, natomiast dorobek kompozytorski w postaci rękopisów w większości znajduje się w Bibliotece Królewskiego Konserwatorium Muzycznego w Brukseli.

${ }^{6}$ Niniejsze zagadnienie szczegółowo omówił Ludwik Gawroński. Zob. L. GAwroŃSKI, Saga rodu Wieniawskich, Lublin 2003.

${ }^{7}$ Autorowi opracowania nie udało się odnaleźć materiałów świadczących o relacjach Józefa Wieniawskiego ze środowiskiem polonijnym na Wyspach Brytyjskich, poza osobami przywołanymi w dalszej części opracowania. 


\section{DZIAŁALNOŚĆ KONCERTOWA}

Pierwsze informacje dotyczące działalności w stolicy Wielkiej Brytanii pojawiły się w maju 1860 r. Wówczas „The Musical World” oznajmiło, że „do Londynu przybył pianista: Józef Wieniawski, brat słynnego skrzypka"8. Prawdopodobnie odwiedził miasto przejazdem, być może w celach turystycznych, bowiem brak jest jakichkolwiek wzmianek o koncertach $\mathrm{z}$ jego udziałem. Podobna sytuacja miała miejsce we wrześniu, kiedy „przejazdem odwiedził Londyn, w drodze z Paryża do Hamburga"9 , co było również krótką wizytą, podczas której Wieniawski jedynie zwiedzał miasto i być może uczestniczył w koncertach znajdując się po stronie publiczności.

Dopiero dziewięć lat później pojawił się Wieniawski w Londynie kolejny raz. Wówczas cieszył się już nie tylko opinią wybitnego pianisty, znanego w różnych częściach Europy, ale również ceniony był za swoją działalność pedagogiczną, którą realizował jako profesor Konserwatorium Muzycznego w Moskwie. Tam prowadził również własną szkołę muzyczną. Pod koniec kwietnia 1869 r. pojawiła się informacja o tym, że: „Pan Józef Wieniawski przybędzie wkrótce do Londynu, gdzie 7 maja wystąpi z koncertem" ${ }^{10}$ w Hanover Square Rooms. Było to kolejne z kameralnych wydarzeń, odbywających się w tym miejscu cyklicznie, w każdy piątek o godzinie piętnastej. Tym razem „w koncercie przyjęli udział śpiewacy: Augusta Goetz i Pan Reinhardt oraz instrumentaliści: H. Vieuxtemps, wiolonczelista Pan Piatti, któremu zaakompaniuje Wilhelm Ganz"11. Wydarzenie spotkało się z dużym zainteresowaniem ze strony lokalnej prasy, bowiem poprzedziła je kilkakrotna zapowiedź. Kolejny koncert $\mathrm{z}$ udziałem artysty został jednak przemilczany. Dopiero 15 maja pojawiła się krótka recenzja z innego występu, jaki miał miejsce w dniu poprzednim. Tym razem był to solowy recital, jaki spotkał się z następującą oceną: ,jego dotyk klawiatury był pełen wigoru, niekiedy elektryzujący. Jakość ta ujawniła się w umiejętnie dobranych utworach. Szczególną uwagę wzbudziło wykonanie etiud i ballady Chopina"12, jednocześnie recenzent podkreślił, że jest „niezbyt jeszcze znany angielskiej publiczności" ${ }^{13}$. W miejscowej prasie przemilczano również niedzielny koncert, podczas którego zaprezentował się powtórnie w solowym repertuarze. Warto

8 „The Musical World” 1860, nr 21, s. 235.

9 "The Musical World" 1860, nr 38, s. 608.

${ }^{10}$ Étranger, „La Revue et Gazette Musicale de Paris” 1869, nr 17, s. 143.

11 „Morning Post” 1869, nr 29.764, s. 1.

12 Music, „Ilustrated London News” 1869, nr 1538, s. 507.

${ }^{13}$ Tamże. 
w tym miejscu zauważyć, że od tego momentu pobytem Wieniawskiego w Londynie zainteresowała się prasa niemiecka. O wspomnianym koncercie poinformowało „Münchener Propyläen”: „Pan Józef Wieniawski w ostatni niedzielny wieczór wystąpił z koncertem w Hanover Square Rooms. Wykonał utwory Chopina i Rubinsteina. Spotkał się z owacyjnym przyjęciem przez miejscową publiczność, pełną podziwu dla wykonań kompozycji swojego rodaka" 14 . Wypowiedź utrzymana w podobnym tonie pojawiła się na łamach „Neue Berliner Musikzeitung”. Redaktor stwierdził, że: „Pan Józef Wieniawski odnosi tutaj wielkie triumfy"15, podając jednocześnie zapowiedź kolejnego koncertu, zaplanowanego na środę 16 czerwca. O szczegółach poinformowało natomiast sobotnie wydanie „Morning Post”: „W koncercie Pana Wieniawskiego udział przyjęli śpiewacy: Anna Regan i Jules Lefort [...]. Wystąpią też instrumentaliści: Pan Ludwig Straus (wiolonczela) i Pan H. Vieuxtemps (skrzypce). Artyści wykonają: Trio D-dur Beethovena, wariacje Mendelssohna, Ernsta Rondo-Papagene i pieśni Brahmsa"16.

O fakcie przypomniał również redagowany przez braci Schott „Süddeutsche Musik-Zeitung”. Anonimowy korespondent wspomniał o ostatnim koncercie, dodając, że Wieniawski: „To artysta wyróżniający się swym warsztatem pianistycznym pod każdym względem" ${ }^{17}$. Obszerna relacja pojawiła się dopiero pod koniec tygodnia. Dowiadujemy się, że „wytrawna publiczność zgromadziła się wczoraj wieczorem w Queen's Concert Room, aby wysłuchać drugiego już koncertu, podczas którego wystąpił Pan Józef Wieniawski”"18, wykonując utwory Chopina i własne. Druga część występu miała charakter kameralny, podczas którego „towarzyszyła mu Pani Anna Regan, będąca młodą o rozwijającym się talencie i słodkim głosie śpiewaczkąa" ${ }^{19}$, po czym opuścił miasto.

Pianista planował odwiedzić Londyn niespełna trzy lata później. W lutym 1872 r. pojawiła się zapowiedź jego przyjazdu: „Pan Józef Wieniawski pianista i brat słynnego skrzypka zapowiedział swój koncert w naszym mieście" ${ }^{20}$, co było jednak jednorazową informacją, a wyjazd nie doszedł do skutku. W kwietniu 1877 r. o kolejnych zamiarach koncertowych w Londynie poinformował „Kurier Warszawski”, gdzie czytamy, że „pianista nasz zamie-

\footnotetext{
14 „Münchener Propyläen” 1869, nr 21, s. 501.

${ }^{15}$ Nachrichten, „Neue Berliner Musikzeitung” 1869, nr 23, s. 192.

16 „Morning Post” 1869, nr 29.800, s. 1.

${ }^{17}$ Nachrichten, „Süddeutsche Musik-Zeitung” 1869, nr 24, s. 96.

${ }^{18}$ M. J. Wieniawski's matinee musicale, „The Morning Advertiser” 1869, nr 24.349, s. 3.

19 Tamże.

${ }^{20}$ „Dwight's Journal of Music” 1872, nr 23, s. 184.
} 
rza udać się do Londynu"21. Pierwsza wiadomość na ten temat w londyńskiej prasie pojawiła się w drugiej połowie maja. Wieniawski brał wówczas udział w koncertach organizowanych przez Rudolpha Ganza w St. James Hall, z udziałem artystów Towarzystwa Filharmonicznego. Pierwszy z nich, podczas którego wykonano Koncert fortepianowy Henry'ego Litolffa, odbył się 26 maja $^{22}$, natomiast kilka dni później pojawiło się sprawozdanie ograniczające się do krótkiej informacji, w której czytamy: „Pan Józef Wieniawski wykonał Koncert fortepianowy Litolffa, pod kierunkiem Pana Juliusza Benedicta"23. Wieniawski pozostał w stolicy Wielkiej Brytanii na dłużej. Biorąc pod uwagę wyłącznie lokalne źródła prasowe, kolejny koncert odbył się dopiero 3 lipca: „Ósmy koncert w Muzycznej Unii odbył się w miniony wtorek wieczorem. Zawierał bardzo interesujący program: Septet Beethovena na instrumenty smyczkowe i dęte, Septet smyczkowy Hummla oraz ustępy solowe na skrzypce i fortepian. W koncercie przyjęli udział: Leopold Auer i Józef Wieniawski" ${ }^{\prime 24}$.

Londyńska prasa pominęła bardzo ważne wydarzenie z udziałem Wieniawskiego, o czym dowiadujemy się z „La Revue et Gazette Musicale de Paris”. Uczestniczył on w koncercie wpisującym się w Handel Festival. Wówczas był to ostatni z koncertów Festiwalu odbywającego się w prestiżowym Crystal Palace. Jak czytamy: „W piątek 29 czerwca, podczas Festiwalu Haendla wystąpił Józef Wieniawski. Wspólnie z Auerem (skrzypce) i Lasserre'm (wiolonczela) artyści zaprezentowali utwory Bacha, Hummla, Beethovena i Chopina" 25 .

Prasa lokalna wspomniała dopiero o koncercie, jaki miał miejsce 8 lipca, być może dlatego, że był on z perspektywy autorów tekstu bardziej istotny: „Towarzystwo Filharmoniczne zamknęło w miniony poniedziałek swój 65. sezon koncertowy, pod kierunkiem Pana Cusinsa" ${ }^{26}$. O koncercie pisano w następujący sposób: „Część instrumentalna złożona była z dwóch części: Koncertu fortepianowego c-moll Beethovena wykonanego przez Pana Józefa Wieniawskiego. Vieuxtempsa Ballade i Polonaise de concert na skrzypce wykonała Pani Marguerite Pommereul"27.

\footnotetext{
21 „Kurier Warszawski” 1877, nr 89, s. 3.

${ }^{22}$ Zob. „Morning Post” 1877, nr 32.731, s. 1.

${ }^{23}$ The Handel Festival, „Ilustrated London News” 1877, nr 1977, s. 10.

${ }^{24}$ The triennial Handel Festival, „Ilustrated London News” 1877, nr 1982, s. 516.

${ }^{25}$ Nouvelles diverses, „La Revue et Gazette Musicale de Paris” 1877, nr 27, s. 215.

26 „Ilustrated London News” 1877, nr 1989, s. 3.

${ }^{27}$ Tamże.
} 
W tym samym czasie o działalności Wieniawskiego w Londynie wspomniano na łamach „Kuriera Warszawskiego”: „w jednym z koncertów w St. James Hall p. Wieniawski zapoznał londyńczyków z nieznanemi im zupełnie kompozycjami Moniuszki" ${ }^{28}$, co było jednocześnie ostatnią informacją dotyczącą tej wizyty w stolicy Wielkiej Brytanii.

Wiadomości o kolejnym pobycie pianisty w mieście są znikome. Ograniczają się bowiem do jednej wzmianki, zamieszczonej w „Kurierze Warszawskim” 11 marca 1880 r. Jak informuje korespondent: „Józef Wieniawski po koncercie $\mathrm{w}$ Londynie, skąd $\mathrm{w}$ dniu wczorajszym wyjechał, powróci do Warszawy" ${ }^{29}$. Była to prawdopodobnie krótka wizyta o charakterze prywatnym, podczas której Wieniawski uczestniczył w koncercie kameralnym. Powrócił tam jeszcze w drugiej połowie maja: „Józef Wieniawski opuścił w dniu wczorajszym Warszawę, udał się do Londynu"30. Pierwszy raz wystąpił w sobotę 12 czerwca, o godzinie trzeciej w południe. Dowiadujemy się, że „w koncercie udział wezmą Panowie: Józef Wieniawski (fortepian), Franz Hugo Floermann (skrzypce) i Herbert Reevers (tenor)" ${ }^{31}$. Dzięki niemu podczas koncertu w Londynie „pierwszy raz wykonana będzie Fantazja węgierska Liszta" ${ }^{32}$. Nie podano jednak bardziej szczegółowych informacji. W poniedziałek 14 czerwca pojawiła się wzmianka o mającym się odbyć dwa dni później koncercie solowym. Jak czytamy: „Pan Józef Wieniawski wystąpi z recitalem w St. James Hall we środę o trzeciej w południe" ${ }^{33}$, co nastąpiło 16 czerwca. Był to jednocześnie występ z udziałem słynnej orkiestry Rudolpha Ganza. Wówczas Wieniawski wspólnie z miejscowymi muzykami wykonał Fantaisie Hongroise Liszta, co spotkało się z przychylną oceną krytyków:

Inna znana praca w programie to Fantaisie Hongroise Liszta na fortepian i orkiestrę. Nie trzeba nic więcej dodawać odnośnie do tego charakterystycznego porywu, ale służyło to również powrotowi pianisty, którego imię znane jest w całej Europie i czerpało z tego faktu dodatkowe zainteresowanie. Pan Józef Wieniawski zbudował swoją reputację poprzez wykonywanie dzieł ze szkoły Liszta. Posiada on łatwość wykonywania i odrobinę koniecznego stylu dla efektów, jakie taka muzyka jest przystosowana produkować, a jeśli czasami jego grze brakuje

28 „Kurier Warszawski” 1877, nr 162, s. 2.

29 „Kurier Warszawski” 1880, nr 55, s. 3.

30 „Kurier Warszawski” 1880, nr 112, s. 3.

${ }^{31}$ Music, „Ilustrated London News” 1880, nr 10.652, s. 1.

32 Tamże.

33 „London Daily News” 1880, nr 10.657, s. 2. 
uroku, nie można jej zarzucić, że kiedykolwiek pragnął blasku. Pan Wieniawski zadomowił się z Fantaisie Hongroise ${ }^{34}$.

Ta pozytywna recenzja Wieniawskiego znajdowała swoją kontynuację w jego późniejszych poczynaniach. W połowie czerwca zamieszczono na łamach prasy informację dotyczącą koncertów kameralnych z udziałem Wieniawskiego i Leopolda Auera: „artyści zagrają we wtorek 22, środę 23 i sobotę 26 czerwca" ${ }^{35}$. Środowy koncert w St. James Hall odbywał się w ramach Festiwalu Haendlowskiego, w którym pianista uczestniczył już kilka lat wcześniej. Wówczas „wykonał kompozycje Beethovena (Sonata fortepianowa Es-dur op. 31) oraz różne dzieła Schumanna, Mozarta, Chopina, Liszta i własne" ${ }^{36}$, natomiast szczegółowa recenzja pojawiła się na łamach „The Era”. Krytyk wypowiedział się następująco: „Gra Pana Wieniawskiego nie miała dość uczuciowego charakteru. Mimo tego była pełna wigoru, a poszczególne części spotykały się z żywiołowymi oklaskami. Ponadto zachwyt wzbudziło jego wykonanie Scherza Chopina, przepełnione energią i środkami ekspresji" ${ }^{37}$. Opinia ta świadczy o podzielonym zdaniu londyńskich komentatorów w stosunku do gry Wieniawskiego. Warto jednak zwrócić uwagę, że jego pobyt w Londynie także i tym razem nie umknął warszawskim korespondentom. W informacji na łamach „Kuriera Warszawskiego” czytamy: „Józef Wieniawski wystąpił $\mathrm{w}$ tych czasach w kilkunastu zbiorowych koncertach w londyńskiej St. James Hall”"38. Jednocześnie pojawiła się zapowiedź koncertów w Niemczech: Wiesbaden, Frankfurcie i Monachium. Ostatnia wiadomość dotycząca pobytu w Londynie pochodzi z 7 lipca. Fakt jednego z koncertów w miejscowej prasie został całkowicie przemilczany. Dowiadujemy się, że Wieniawski: „W tych dniach wystąpił on w wieczorze Niemieckiego Stowarzyszenia dla Muzyki i Sztuki"39, jednak nie podano bardziej precyzyjnych informacji.

W połowie czerwca $1881 \mathrm{r}$. rozpoczął się kolejny pobyt w stolicy Wielkiej Brytanii. Dzięki korespondentom jednego z miejscowych czasopism 16 czerwca dowiadujemy się, że Wieniawski „dał wczoraj wieczorem pierwszy z dwóch wcześniej przez nas ogłaszanych koncertów. Wystąpił w St. James Hall pre-

\footnotetext{
${ }^{34}$ Mr. Ganz's orchestral concerts, „Pall Mall Gazette” 1880, nr 4776, s. 11.

35 „London Daily News” 1880, nr 10.662, s. 1.

${ }^{36}$ „Ilustrated London News” 1880, nr 10.662, s. 3.

${ }^{37}$ M. Wieniawski's pianoforte recital, ,The Era” 1880, nr 24, s. 7.

38 „Kurier Warszawski” 1880, nr 140, s. 3.

39 „Kurier Warszawski” 1880, nr 148, s. 3.
} 
zentując pełnię swoich możliwości”" ${ }^{40}$. Występ również tym razem poddano ocenie. Uwaga krytyka skupiła się wokół Sonaty wiolonczelowej E-dur op. 26:

Jest to kunsztowna kompozycja odznaczająca się płynną melodyką, rzadko dziś spotykaną we współczesnych utworach instrumentalnych. W materiale tematycznym allegra i jego późniejszym traktowaniu odnaleźć można wiele interesujących miejsc. Andantino natomiast jest delikatne i pełne wdzięku, a Finale nasycone energią. Gra Pana Hollmana była delikatna i subtelna, choć miejscami nie zabrakło brawury ${ }^{41}$.

Pozytywnie oceniona została interpretacja dzieł Chopina, jednak bez wskazania na konkretne utwory. Był to bardzo intensywny czas, obfitujący w liczne koncerty, za sprawą pobytu w Londynie wielu wybitnych muzyków. Jedno z czasopism odnotowało: „Nigdy wcześniej tutaj, w ciągu jednego koncertu nie pojawiło się tylu znakomitych pianistów, pochodzących z różnych części Europy: Antoni Rubinstein z Rosji, Józef Wieniawski z Polski, Hans von Bülow z Drezna i Sophie Menter z Wiednia"42.

Niedługo później pojawiły się zapowiedzi dotyczące kolejnych koncertów w St. James Hall. Były to dwa recitale fortepianowe, z których „pierwszy został ogłoszony na najbliższą środę"43 - 22 czerwca. Natomiast ponownie zaprezentował się w poniedziałek 28 czerwca. Jak zauważył krytyk, „wykonał recital złożony wyłącznie z dzieł Chopina" ${ }^{44}$, co stało się już tradycją w działalności koncertowej Wieniawskiego.

Wspomniana wizyta $\mathrm{w}$ Londynie była jednym $\mathrm{z}$ ostatnich przystanków przed wyjazdem do stolicy Belgii. W połowie 1882 r. pojawiła się informacja o tym, że: „Pan Józef Wieniawski obrał Brukselę jako miejsce stałego zamieszkania"45, co jednak nie przeszkodziło mu w późniejszych podróżach po Europie. Pod tym względem intensywnie upływały kolejne lata. Wieniawski koncertował niemal nieprzerwanie, odwiedzając najbardziej prestiżowe ośrodki kulturalne Starego Kontynentu.

W kwietniu 1887 r. o kolejnych planach koncertowych poinformowało „Le Figaro”, z którego dowiadujemy się, że: „Pan Józef Wieniawski wkrótce

\footnotetext{
40 „London Evening Standard” 1881, nr 17.756, s. 3.

${ }^{41}$ Tamże.

42 „Monmoutshire Merlin” 1881, nr 2.711, s. 6.

${ }^{43}$ Music, „Ilustrated London News” 1881, nr 2196, s. 599.

${ }^{44}$ Music, „Ilustrated London News” 1881, nr 2198, s. 607.

${ }^{45}$ Berichte, „Musikalisches Wochenblatt” 1882, nr 19, s. 227.
} 
wyruszy do Londynu, gdzie wystąpi prezentując własne kompozycje"46, co nastąpiło dwa miesiące później. W połowie czerwca „Morning Post” zawiadomiło o koncercie kameralnym zaplanowanym na czwartek - 16 czerwca, o godz. 15:00 w St. James Hall. Zgodnie z zapowiedzią „w koncercie towarzyszyć Panu Wieniawskiemu będą: Pani Wilma Norman-Néruda, Pan Carlo Patti, Pani Jane de Vigne" ${ }^{47}$. Wówczas zaprezentował Trio op. 40 własnej kompozycji. Co ciekawe, zapewne ze względu na towarzyszących mu artystów występ wzbudził szczególne zainteresowanie w prasie francuskojęzycznej. Korespondent „Le Ménestrel. Musique et Théatres” stwierdził, że „recital, z jakim Pan Józef Wieniawski wystąpił w Londynie, był bardzo udany. Publiczność oklaskiwała artystę, który przedstawił się w podwójnej roli: pianisty i kompozytora" ${ }^{48}$, wspólnie z Wilmą Neruda (skrzypce) i Carlo Pattim (wiolonczela) zaprezentował własne Trio fortepianowe op. 40, w którym „szczególnie andante i finale były oklaskiwane”49. Po tym koncercie artysta wyruszył w dalszą podróż, do Niderlandów.

W 1891 r. Wieniawski ponownie udał się do Wielkiej Brytanii, prosto z kilkumiesięcznego pobytu w Rosji. Pod koniec maja „Morning Post” poinformowało, że „w następny wtorek - 2 czerwca wystąpi Pan Paderewski z koncertem symfonicznym w St. James Hall" ${ }^{50}$. Pomimo tego, że nie ma wzmianki o obecności Wieniawskiego, należy zwrócić uwagę na zaprezentowany program, w którym znalazła się jego Overture Dramatique „, Guillaume de Taciturne". O osobistym udziale lublinianina w koncercie dowiadujemy się ze wzmianki: „w następny piątek [21 czerwca] w St. James Hall wystąpi Pan Józef Wieniawski. Towarzyszyć mu będą panowie: Hollman i Paderew-

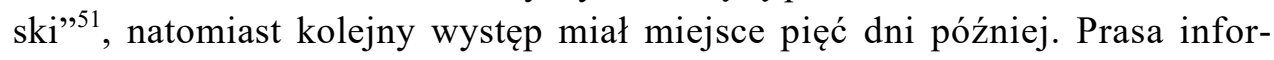
mowała, że: „Koncert fortepianowy Józefa Wieniawskiego w st. James Hall odbędzie się 26 czerwca o godzinie trzeciej" ${ }^{52}$, podczas którego również wystąpili Joseph Hollman i Ignacy Jan Paderewski. Program natomiast przedstawiał się następująco: „Artyści wykonają wspólnie Sonatę wiolonczelowa op. 26 i Fantaisie op. 42 na dwa fortepiany. Pan Wieniawski w części solowej odegra: 3me Polonaise op. 27, Romances sans Paroles, Etude de

\footnotetext{
${ }^{46}$ Nouvelles diverses, „Le Figaro” 1887, nr 140, s. 3.

${ }^{47}$ „Morning Post” 1887, nr 35.876, s. 8.

48 "Le Ménestrel. Musique et Théatres” 1887, nr 32, s. 255.

49 „Le Guide Musical” 1887, nr 26-27, s. 172.

50 „Morning Post” 1891, nr 37.112, s. 1.

51 „Morning Post” 1891, nr 37.133, s. 1.

52 „The St. James's Gazette” 1891, nr 3443, s. 1.
} 
Concert op. 33, Sur l'Océan op. 28"53. Jak wynika z programu, był to koncert, podczas którego Wieniawski zaprezentował wyłącznie własną twórczość, co nie należało do rzadkości. Podobne recitale odbywały się już w Warszawie w latach siedemdziesiątych oraz w Paryżu i Brukseli. Był to jednocześnie ostatni występ podczas tej wizyty w Londynie.

Kolejny raz Wieniawski odwiedził miasto w 1899 r. Dowiadujemy się, że „dobrze znany pianista i kompozytor - Józef Wieniawski wystąpi z koncertem w St. James Hall w następny czwartek" ${ }^{54}$. Autor wzmianki zapowiedział wykonanie utworów Webera, Beethovena i Chopina. W części kameralnej, pod kierunkiem Ernsta Cavoura zaprezentowano również Kwartet smyczkowy a-moll op. 32. W wydarzeniu tym, jakie miało miejsce 11 maja o godz. 11, udział wzięli: Theodore Werner, Alfred Hobday, Haydn Inwards i W.F. Whitehouse ${ }^{55}$. Tydzień później „The Stage” zamieściło obszerne sprawozdanie. Pojawiła się jedyna za życia kompozytora informacja dotycząca wykonania Kwartetu:

Ci doświadczeni instrumentaliści stworzyli z niemałym wysiłkiem całkiem interesujący i nieznajdujący porównania z innymi Kwartetami. Po stłumionym i żmudnym Allegro nastąpiło Andante Cantabile, zachwycające melodyjnym urokiem i ukazujące powiązania ze stylem muzyki kościelnej. W Scherzo kompozytor ukazuje swego rodzaju muzyczny humor we fragmentach o żartobliwej wymianie dźwięków pomiędzy różnymi instrumentami, natomiast finał doprowadza dzieło do skutecznej konkluzji ${ }^{56}$.

Poza tym pianista zaprezentował kolejne własne kompozycje zawarte w opus 39. Koncert nie spotkał się jednak ze zbyt dużym zainteresowaniem, biorąc pod uwagę poprzednie, co również zauważyła prasa: „gdyby Pan Józef Wieniawski pojawił się w bardziej sprzyjającym czasie, być może przyciągnąłby większą uwagę szerszej publiczności, co ostatecznie stanowiło największe utrudnienie"57. Był to jedyny koncert Wieniawskiego w Londynie podczas tej wizyty. Niemniej jednak zwróciło to uwagę niemieckich krytyków, bowiem recenzję przedrukowało „Signale für die Musikalische Welt"58. Przywołany koncert był jednocześnie ostatnim występem w stolicy Wielkiej Brytanii.

\footnotetext{
53 Tamże.

54 „The Referee” 1899, nr 18, s. 5.

${ }^{55}$ Zob. „The Daily Telegraph” 1899, nr 13.730, s. 1.

56 Joseph Wieniawski's concert, „The Stage” 1899, nr 948, s. 18.

57 Tamże.

${ }^{58}$ Zob. Dur und moll, „Signale für die Musikalische Welt” 1899, nr 40, s. 640.
} 
Działalność Wieniawskiego w Londynie nie ograniczyła się jednak wyłącznie do koncertów, co zauważyła lokalna prasa. Z dużym zainteresowaniem spotkały się zagadnienia dotyczące fortepianu dwuklawiaturowego firmy Mangeot, którego był pomysłodawcą.

\section{FORTEPIAN DWUKLAWIATUROWY ${ }^{59}$}

Idea powstania fortepianu dwuklawiaturowego zrodziła się jeszcze w latach sześćdziesiątych, gdy Wieniawski pełnił funkcję profesora Konserwatorium Muzycznego w Moskwie. W swoich zamierzeniach spotkał się ze wsparciem Juliusza Zarębskiego, z którym opracował projekt instrumentu. Wyłącznie Zarębski uczestniczył w prezentacji, dlatego też rola Wieniawskiego w tym zakresie została $\mathrm{z}$ czasem zmarginalizowana. Według Léona Delcroix: „Józef odmówił udziału na wystawie w 1878 r., nie mając pewności, czy umiejętności wynalazcy zostaną docenione" ${ }^{60}$. To również Zarębski opracował broszurę zawierającą instrukcję obsługi do gry na fortepianie ${ }^{61}$, co nie podważa zasług brata słynnego skrzypka.

W sierpniu 1878 r. szczegółowo zagadnienie to jako pierwsze poruszyło czasopismo „Fifeshire Journal”. Autor swoją wypowiedź rozpoczął od zarysowania historii fortepianu, tym samym wskazując na instrument o dwóch klawiaturach, jako kolejny etap jego rozwoju. Obawy Wieniawskiego okazały się zasadne. Jak bowiem czytamy: „Stworzono nowy instrument, który został użyty po raz ostatni 10 maja i nie okazał się być pożądanym" ${ }^{62}$, jednak autor informacji dokonał szczegółowej analizy nie tylko instrumentu, ale również podjął się recenzji koncertu, po którym napisał:

Są to dwa osobne pianina, przypominające jedno, ale z dwiema klawiaturami jedna powyżej dla lewej ręki, a druga poniżej dla prawej. Stworzenie podwójnej klawiatury to sama w sobie radykalna zmiana i to zmiana również, jeśli chodzi o układ ludzkich rąk. Z natury układają się one w przeciwnych do siebie kierunkach. Przy takim stanie rzeczy ruchy lewej ręki na zwyczajnej klawiaturze są nienaturalne, $\mathrm{z}$ tego też powodu prawa ręka przemieszczając się z lewej strony na

\footnotetext{
${ }^{59} \mathrm{~W}$ niniejszej publikacji ograniczymy się wyłącznie do recepcji zagadnienia na podstawie brytyjskiej prasy.

${ }^{60}$ L. Delcroix, Joseph Wieniawski, Bruxelles 1908, s. 6.

${ }^{61}$ Zob. J. ZARĘBSKI, Le Piano á claviers renversés de MM. Mangeot Fréres. Ses ressurces au point du vue de la composition et de la virtuosité avec des examples à l'appuis, Paris 1878.

${ }^{62}$ „Fifeshire Journal” 1878, nr 2276, s. 3.
} 
prawą, lub z dźwięków niższych do tych wyższych, sprawia, że kciuk jest pierwszym palcem a mały palec ostatnim. Przy nowej metodzie na klawiaturze dla lewej ręki niskie tony zaczynają się u prawej ręki i rosną do rejestru wyższego w stronę lewą, podczas gdy klawiatura dla prawej ręki pozostaje tam gdzie obecnie. Pierwsza korzyść osiągnięta $w$ ten sposób ma znaczenie dla grającego, mianowicie palcowanie tych samych fragmentów będzie identyczne dla obu rą $k^{63}$.

Dołączenie zatem drugiej klawiatury o odwrotnym układzie klawiszy stwarza nowe możliwości pod względem wykonawczym, co determinuje układ rąk. W dalszej części wypowiedzi autor porównał zamierzenia twórcy do próby odwzorowania orkiestry - poszczególnych sekcji instrumentów. Jego zdaniem zaproponowane rozwiązanie stwarza nowe możliwości w zakresie próby ich odwzorowania. Osobny akapit poświęcono ocenie prezentacji utworów. Juliusz Zarębski wykonał między innymi Rapsodię węgierska Liszta. Dowiadujemy się, że: „Gra Pana Juliusza Zarębskiego została ciepło przyjęta, a on sam został jednogłośnie poproszony o powtórzenie swojego solo, dla którego zastąpił mało interesującą Étude, jako sposób na pokazanie możliwości nowego instrumentu" ${ }^{64}$. Według autora niniejszej wypowiedzi potrzeba jeszcze czasu, aby poznać pełnię możliwości nowo powstałego instrumentu. Zauważa, że: „Nowe pianino podwójne w odniesieniu do zwykłych instrumentów uważa się za zajmujące taką samą pozycję, jak światło elektryczne w stosunku do benzyny. Posiada nieograniczone możliwości, ale faktyczne korzyści płynące z jego użytkowania są wciąż odkrywane"65.

Anonimowy recenzent pozostawił zatem otwarte pole do dyskusji nad nowo zaprezentowanym instrumentem. W październiku natomiast zagadnienie podjął jeden z krytyków na łamach „Ilustrated Sporting and Dramatic News", na samym początku przywołując wypowiedź Franciszka Liszta, który do instrumentu miał ustosunkować się następująco: „Wszystko co może zostać wykonane na pojedynczej klawiaturze zostało już wykonane, a przyszłość należy do pianina, które nie odbiegając od charakteru instrumentu, oferuje nowe możliwości" ${ }^{66}$. Węgierski pianista - twórca poematu symfonicznego, będąc otwartym na nowe wyzwania pochwalił wynalazek swojego ucznia, który jego zdaniem stwarza kolejne możliwości, bowiem wszystkie dotychczasowe rozwiązania zostały wyczerpane. Niemniej jednak

\footnotetext{
63 Tamże.

${ }^{64}$ Tamże.

${ }^{65}$ Tamże.

${ }^{66}$ Covent Garden concerts, „Ilustrated Sporting and Dramatic News” 1878, nr 247, s. 126.
} 
nigdy nie zasiadł przy fortepianie dwuklawiaturowym. Brytyjski dziennik zamieścił również wypowiedź jego twórcy. Oskar Comettant stwierdził:

Bezsporne jest, że pomysły w muzyce dopasowują się do instrumentu, na którym ktoś tworzy - jakość jego brzmienia, kierunek i geniusz. Biorąc pod uwagę tylko instrumenty klawiszowe, łatwo zauważyć, że przemyślenia kompozytorów, którzy tworzyli na dane instrumenty, organy czy pianino, zostały zmodyfikowane zgodnie z udoskonaleniami wprowadzonymi przez producenta. Liszt nigdy nie napisałby swoich koncertów i wielkich wirtuozerskich fantazji na wirginał, szpinet lub nawet na wcześniejszy rodzaj fortepianu ${ }^{67}$.

Utwierdzał on w przekonaniu, że instrument posiadając dwie klawiatury, w tym wypadku odwrotne, musi oferować szerszy zakres możliwości. Wieniawski, w przeciwieństwie do Zarębskiego, nie napisał jednak żadnej kompozycji na fortepian dwuklawiaturowy. Sporządził jedynie transkrypcję Etiudy a-moll op. 25 no. 11.

\section{WYDAWNICTWA}

Mówiąc o związkach Józefa Wieniawskiego z Wielką Brytanią, warto na chwilę zatrzymać się nad zagadnieniem wydawnictw poszczególnych kompozycji, jakie ukazały się w Londynie. W tym miejscu należy zwrócić uwagę na dwa utwory. W $1855 \mathrm{r}$. nakładem oficyny kierowanej przez francuskiego kompozytora i krytyka muzycznego niemieckiego pochodzenia, ukazała się w Londynie Polka brillante D-dur op. $11\left(\mathrm{~N}^{\circ} 7628\right)^{68}$ - jedna z młodzieńczych miniatur będących owocem studiów w Paryżu. Zgodnie z informacją zamieszczoną na pierwodruku, 9 stycznia 1877 r. w Societé Philharmonique á Londres miało miejsce pierwsze wykonanie Cadenza pour le 3 me Concerto pour le Piano de Beethoven op. 37 - Kadencji do III Koncertu fortepianowego c-moll op. 37 Ludwika van Beethovena. W stolicy Wielkiej Brytanii utwór ukazał się nakładem działającej tam od 1870 r. oficyny.

\footnotetext{
${ }^{67}$ Tamże.

${ }^{68}$ J. WiENIAWSKI, Polka brillante op. 11, Londres 1855.
} 


\section{BIBLIOGRAFIA}

\section{Literatura}

ChAmczyк E., Londyński epizod Apolinarego Kątskiego (1838), „Kwartalnik Młodych Muzykologów UJ" 2019, nr 40 (1), s. 5-25.

Delcroix L., Joseph Wieniawski, Bruxelles 1908.

GAWROŃSKi L., Saga rodu Wieniawskich, Lublin 2003.

RZEPECKI K., Józef Wieniawski (1837-1912) - katalog twórczości, Lublin: Polihymnia 2021.

TERLECKA M., Irène Régine Wieniawska - próba rekonstrukcji życia i twórczości, „Kwartalnik Młodych Muzykologów UJ” 2019, nr 42 (3), s. 33-52.

WIENIAWSKI J., Polka brillante op. 11, Londres 1855.

ZAMOYSKi A., Chopin, Warszawa: PIW 2010.

ZARĘBSKI J., Le Piano á claviers renversés de MM. Mangeot Fréres. Ses ressurces au point du vue de la composition et de la virtuosité avec des examples à l'appuis, Paris 1878.

\section{Prasa}

„Dwight's Journal of Music” 1872, nr 23

„Fifeshire Journal” 1878, nr 2276

„Ilustrated London News” 1869, nr 1538; 1877, nr 1977, nr 1982, nr 1989; 1880, nr 10.652, nr 10.662; 1881, nr 2196, nr 2198

„Ilustrated Sporting and Dramatic News” 1878, nr 247

„Kurier Warszawski” 1877, nr 89, nr 162; 1880, nr 55, nr 112, nr 140, nr 148

„La Revue et Gazette Musicale de Paris” 1869, nr 17; 1877, nr 27

„Le Figaro” 1887, nr 140

„Le Guide Musical” 1887, nr 26-27

„Le Ménestrel. Musique et Théatres” 1887, nr 32

„London Daily News” 1880, nr 10.657, nr 10.662

„London Evening Standard” 1881, nr 17.756

„Monmouthshire Merlin” 1881, nr 2.711

„Morning Post” 1869, nr 29.764, nr 29.800; 1877, nr 32.731; 1887, nr 35.876; 1891, nr 37.112; nr 37.133

„Musikalisches Wochenblatt” 1882, nr 19

„Münchener Propyläen” 1869, nr 21

„Neue Berliner Musikzeitung” 1869, nr 23

„Pall Mall Gazette” 1880, nr 4776

„Signale für die Musikalische Welt” 1899, nr 40

„Süddeutsche Musik-Zeitung” 1869, nr 24

„The Daily Telegraph” 1899, nr 13.730

„The Era” 1880, nr 24 
„The Morning Advertiser” 1869, nr 24.349

„The Musical World” 1860, nr 21, nr 38

„The Reveree” 1899, nr 18

„The St. James's Gazette” 1891, nr 3443

„The Stage” 1899, nr 948

\section{DZIAŁALNOŚĆ JÓZEFA WIENIAWSKIEGO W LONDYNIE - ANALIZA ŹRÓDEŁ}

\section{Streszczenie}

Józef Wieniawski, należący do grona najwybitniejszych polskich kompozytorów przełomu XIX i XX wieku, jeszcze za życia zyskał miano kosmopolity - artysty wędrującego, który odwiedzał najodleglejsze zakątki Europy, koncertując przed publicznością w najbardziej prestiżowych ośrodkach Starego Kontynentu. Na podstawie zgromadzonych źródeł i przeprowadzonej analizy należy stwierdzić, że Londyn był jednym z najczęściej odwiedzanych miast przez brata słynnego skrzypka, zapewne z powodów rodzinnych. Analiza zgromadzonych źródeł pozwoliła na odtworzenie fragmentu ścieżki artystycznej, ujawniając tym samym zapomniane fakty z życia artysty.

Słowa kluczowe: Józef Wieniawski; Henryk Wieniawski; polska muzyka w Londynie; Polacy w Londynie

\section{JOSEPH WIENIAWSKI'S ARTISTIC ACTIVITY IN LONDON - ANALYSIS OF SOURCES}

\section{Summary}

Joseph Wieniawski is among the most outstanding, acknowledged and recognized Polish composers living and creating at the turn of the $20^{\text {th }}$ century. Over the years, he's gained a welldeserved name as a real cosmopolitan, a traveling artist who performed in front of the most noble public, in the most prestigious centers and concert halls all over Europe. The collected source material reveals the city of London as his favourite destination, probably for family reasons. The analysis of resources made it possible to recreate fragments of Józef Wieniawski's artistic path, bringing forgotten facts from the artist's life.

Keywords: Joseph Wieniawski; Henry Wieniawski; Polish music in London; Poles in London 